\title{
Rhabdomyomatous mesenchymal hamartoma: a case report
}

\section{Hamartoma mesenquimal rabdomiomatoso: um relato de caso}

Fernanda Alves Luiz Rodrigues ${ }^{1}$; Maria Auxiliadora de Paula Carneiro Cysneiros²; Rubson Rodrigues Júnior ${ }^{3}$; Denis Masashi Sugita ${ }^{1}$

\begin{abstract}
The rhabdomyomatous mesenchymal hamartoma (RMH) is a rare type of hamartoma, composed of randomly arranged striated muscle fibers in dermis and subcutaneous tissue, associated with normal mesenchymal elements. Our objective is to report a case of this rare entity that occurred in the nasal dorsum of a 4-year-old child.
\end{abstract}

Key words: hamartoma; mesenchymal; rhabdomyomatous; striated muscle; skin.

\section{INTRODUCTION}

Originally described in 1986 by Hendrick et al. as striated muscle hamartoma, the rhabdomyomatous mesenchymal hamartoma (RMH) of the skin is a rare congenital tumor that affects predominantly the face and neck of newborns, with rare cases reported in the literature ${ }^{(7,10,20)}$.

The RMH occurs as a single or multiple lesions, generally polypoid, typically located in the midline ${ }^{(19)}$, and is characterized by the presence of mesenchymal elements (adipose, connective, vascular, and nervous tissues) and striated muscles, randomly arranged in dermis and subcutaneous tissues ${ }^{(7,15,19,20)}$.

\section{CASE REPORT}

A 4-year-old male child presented with a hardened welldelimited congenital solid tumoration in nasal dorsum. His mother reported slow growth in recent years, and denied fistulization or nasal obstruction.

The computed tomography (CT) scan revealed a solid ovalshaped nodule enhanced after contrast, superficially located in the nasal dorsum, in the right paramedian position, causing discrete adjacent bone erosion, and measuring approximately $1 \mathrm{~cm}$ in diameter, with a nonspecific appearance (Figure 1).

Excision of the lesion was carried out, and followed by good scarring.

The patient has so far presented no symptoms and signs of recurrence.

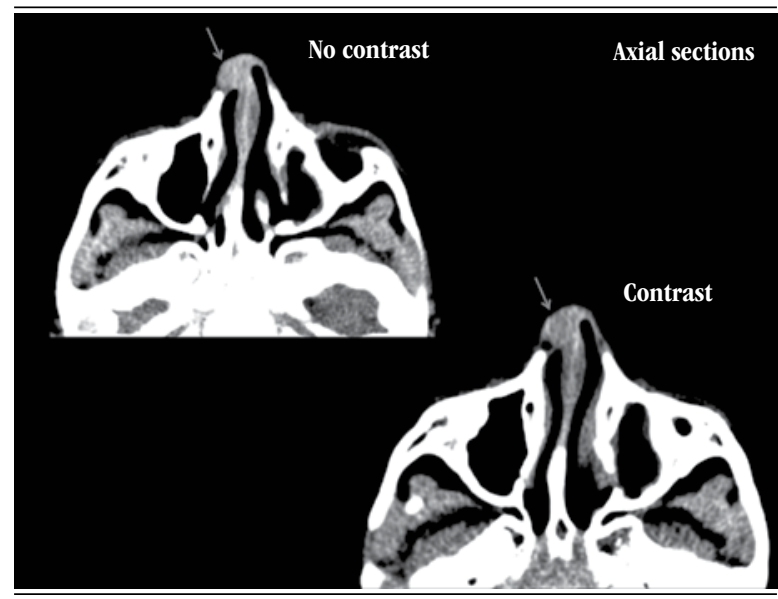

FIGURE 1 -Post contrast CT image reveals an enhanced lesion in nasal dorsum CT: computed tomography.

First submission on 03/02/14; last submission on 03/02/14; accepted for publication on 16/02/14; published on 20/02/14

1. Resident in Pathology at Hospital das Clínicas of Universidade Federal de Goiás (HC/UFG).

2. Master's degree in Pathology from UFG; physician at the Pathology Service at HC/UFG.

3. Resident in Internal Medicine at HC/UFG. 


\section{Anatomopathological study}

Two irregularly-shaped brownish-gray fibroelastic tissue fragments were examined, with the largest measuring $0.8 \mathrm{~cm}$ in its longer diameter.

By microscopy, a hamartomatous lesion composed of dense collagen bundles was observed, with randomly intermingled striated skeletal muscle fibers. Also, proliferated vessels, small foci of mature adipose tissue and a single lobule of adnexal gland (Figures $\mathbf{2}$ and $\mathbf{3}$ ) were identified. At the periphery of the lesion, there was well-structured mature cartilaginous tissue without atypia.

Immunohistochemistry (IHC) was positive for desmin (Figure 4) and HHF-35 (Figure 5) in the striated muscle fibers.

The previously described histomorphological and IHC findings are compatible with the picture of RMH.

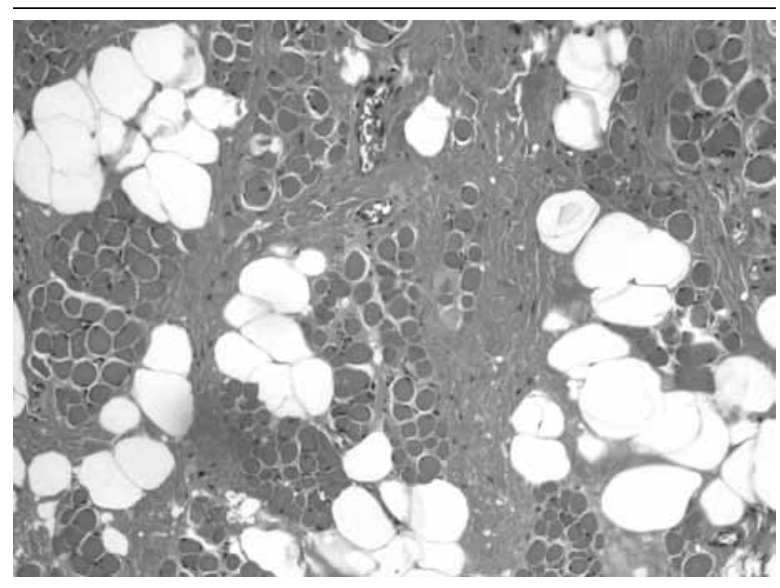

FIGURE 2 - HEE stain, skeletal striated muscle fibers, intermingled with adipocytes HEE: hematoxylin and eosin

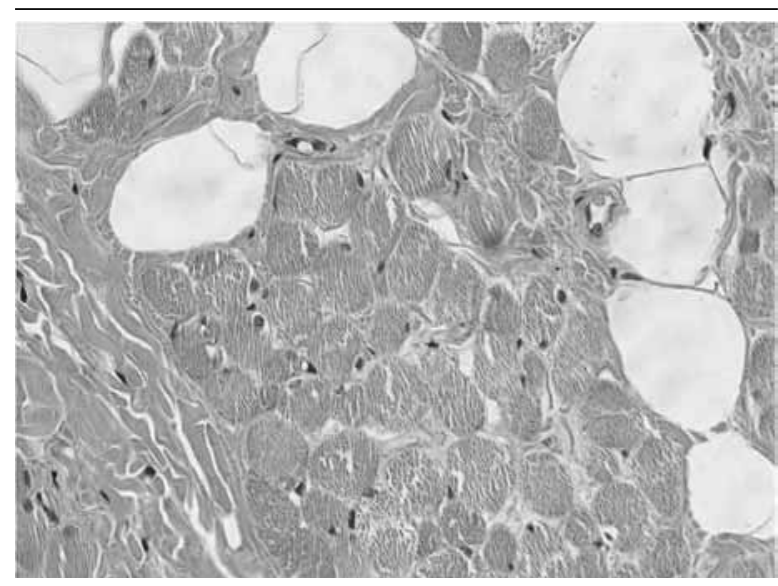

FIGURE 3-HEE stain, striations of skeletal muscle fibers are precisely observed HEE: bematoxylin and eosin.

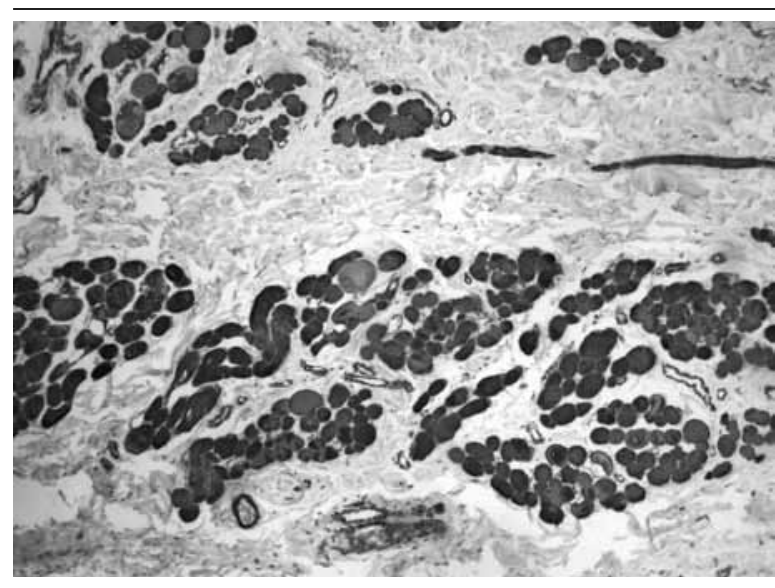

FIGURE 4-IHC shows positivity for desmin in the skeletal muscle fibers IHC: immunohistochemical.

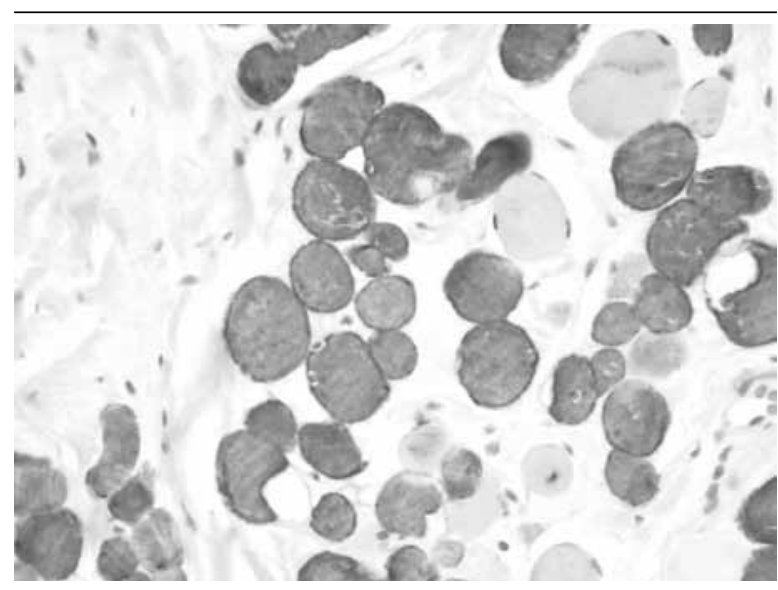

FIGURE 5 -IHC study shows positivity for HHF35 in the skeletal muscle fibers IHC: immunohistochemical.

\section{DISCUSSION}

Hamartomas are malformations composed of tissue elements normally found at the lesion site, yet arranged in a disorganized manner ${ }^{(2,5,12,15)}$.

RMHs are hamartomatous lesions more commonly reported in head and neck ${ }^{(4,6,17,19)}$, with rare cases in perineal regions ${ }^{(14,18)}$.

Lesions typically occur in children and are usually present since birth ${ }^{(8)}$. They generally present as a small solitary domeshaped papule, or a polypoid pedunculated lesion, ranging in size from few millimeters to $1-2 \mathrm{~cm}^{(6)}$. There are reports about this entity in adults, but it is not known whether the lesions were present since birth ${ }^{(20)}$.

The etiology is unknown, however, RMH is believed to result from an abnormality in the migration of mesodermal 
tissue during embryogenesis or from genetic defects ${ }^{(3,11,18,19)}$, as it is associated with other congenital defects like the amniotic band syndrome, Delleman syndrome, and Goldenhar syndrome ${ }^{(19)}$.

Almost all the lesions occur in males, with rare cases being described in females ${ }^{(6,20)}$.

Microscopically these lesions are constituted by striated muscle fibers randomly distributed, intermingled with mature adipose tissue, collagen bands, blood vessels, and elastic fibers ${ }^{(1,16)}$. Adnexal structures interwoven with the muscle bundles are reported. However, it has been questioned if the presence of these structures is an incidental finding, as adnexal glands may normally be present in the reticular dermis ${ }^{(6)}$.

IHC in RMH shows positivity for actin, desmin, and myoglobin in the skeletal muscle fibers.

Differential diagnoses include superficial lipomatous nevus, fibrous hamartoma of infancy, neuromuscular choristoma (benign Triton tumor), rhabdomyoma and cutaneous embryonal rhabdomyosarcoma. The superficial lipomatous nevus shows mature adipose tissue in dermis, but lacks elements of skeletal muscle. The fibrous hamartoma of infancy contains a mixture of mature adipose tissue, collagen bands, but also lacks the fibers of skeletal muscle ${ }^{(20)}$. The neuromuscular choristoma (benign Triton tumor) is a subcutaneous lesion composed of skeletal muscle fibers and neural tissue ${ }^{(13)}$. The rhabdomyoma contains variable amounts of myxoid and fibrous tissue, with mesenchymal undifferentiated cells and fetal striated muscle ${ }^{(8,16)}$. Lastly, the cutaneous embryonal rhabdomyosarcoma represents a rare and much less differentiated entity ${ }^{(4,20)}$.

Surgery is the treatment of choice in these cases, with complete lesion resection. So far, recurrences have not been reported after surgical resection of these nodules $(8,12,19,20)$.

\section{CONCLUSION}

We report a case of RMH in a 4-year-old child, whose clinical, radiological, macroscopical, histopathological and immunohistochemical findings are compatible with those described in this rare entity.

Although RMHs are rare and benign lesions, their association with other congenital anomalies and embryological errors must always be evaluated in patients with this diagnosis.

\section{RESUMO}

O bamartoma mesenquimal rabdomiomatoso (HMR) representa um raro tipo de hamartoma composto por fibras musculares estriadas dispostas aleatoriamente em derme e tecido subcutâneo, associadas a elementos mesenquimais normais. O nosso objetivo é relatar um caso desta rara entidade que ocorreu no dorso nasal de uma criança de 4 anos.

Unitermos: hamartoma; mesenquimal; rabdomiomatoso; músculo estriado; pele.

\section{REFERENCES}

1. BALL, E. A. et al. Rhabdomyomatous mesenchymal hamartoma resembling scleroderma "en coup de sabre": a case report and literature review. Br J Dermatol, v. 162, n. 1, p. 222-4, 2010.

2. BARNHILL, R. et al. Dermatopathology. 3 ed. N.Y: Mc Graw Hill, p. $857,2010$.

3. BERNAL-MAÑAS, C. M. et al. Hamartoma mesenquimal rabdomiomatoso.An Pediatr (Barc), v. 78, n. 4, p. 260-2, 2013.

4. BRINSTER, N. K.; FARMER, E. R. Rhabdomyomatous mesenchymal hamartoma presenting on a digit. J. Cutan Pathol, , v. 36, n. 1, p. 61-3, 2009 .

5. DAL VECHIO, A. et al. Rhabdomyomatous (mesenchymal) hamartoma presenting as haemangioma on the upper lip: a case report with immunohistochemical analysis and treatment with high-power lasers. Case Rep Dent, v. 2013; 2013.

6. DÍAZ- PEREZ, J. A. et al. [Rhabdomyomatous mesenchymal hamartoma]. Actas Dermosifiliogr, v. 99, n. 6, p. 474-6, 2008.

7. GNEPP, D. Diagnostic surgical pathology of the head and neck. $2 \mathrm{ed}$. Philadelphia: Saunders (Elsevier), 2009. p. 1004

8. HAN, S. H. et al. Rhabdomyomatous mesenchymal hamartoma of the vagina. Pediatr Dermatol, v. 26, n. 6, p. 753-5, Nov/Dec 2009.

9. JOHNSTON, R. Weedon's skin pathology essentials. 1. ed. Churchill Livingstone (Elsevier), 2012. p. 662.

10. KANG, J. W.; PARK, H. S.; KIM, J. H. Rhabdomyomatous mesenchymal hamartoma of nasal vestibule.J Craniofac Surg, v. 24, n. 5, p. e481-3, 2013.

11. KIM, H. S. et al. Rhabdomyomatous mesenchymal hamartoma.J Eur Acad Dermatol Venereol, v. 21, n. 4, p. 564-5, 2007. 
12. LARA, B. W. et al. Hamartoma mesenquimal rabdomiomatoso. Rev Esp Patol, v. 37, n. 4, p. 429-32, 2004.

13. READ, R. W. et al. Rhabdomyomatous mesenchymal hamartoma of the eyelid: report of a case and literature review. Ophthalmology, v. 108 , n. 4, p. 798-804, April 2001.

14. RODRÍGUEZ, L. G.; RODRÍGUEZ, Á.; VARGAS, N. Hamartoma mesenquimal rabdomiomatoso. Rev Asoc Colomb Dermatol Cir Dermatol, v. 15, n. 3, p. 221-3, Sept. 2007.

15. ROSAI, J. Rosai and Ackerman's Surgical Pathology. 10 ed. Missouri: Mosby (Elsevier), 2011. p.182.

16. ROSEMBERG, A. S.; KIRK, J.; MORGAN, M. B. Rhabdomyomatous mesenchymal hamartoma: an unusual dermal entity with a report of two cases and a review of the literature. J Cutan Pathol, v. 29, n. 4 , p. 238-43, 2002

17. VAIDYNATHAN, M.; WILLIANS, C. E. C. S.; MORGAN, P. R. Rhabdomyomatous mesenchymal hamartoma of the tongue. BMJ Case Reports, 2011; 2011. p. 1-2.

18. WANG, J.-R. et al. Rhabdomyomatous mesenchymal hamartoma associated with congenital anomalies: report of an unusual perineal case. Dermatol Sinica, v. 26, p 93-8, 2008.

19. WEEDON, D. Weedon's skin pathology. 3 ed. Mosby (Elsevier), 2012. p. 662 .

20. WEISS, S.; GOLDBLUM, J. EnzingerE Weiss's soft tissue tumors. 5. ed. Missouri: Elsevier, 2008. p. 591. 